\title{
IMMUNOPHENOTYPING IN PRESUMED OCULAR HISTOPLASMOSIS LIKE RETINOPATHY
}

\author{
P. R. HODGKINS, A. C. LANE, I. H. CHISHOLM, M. J. ABSOLON, A. R. ELKINGTON \\ and J. L. SMITH \\ Southampton
}

\begin{abstract}
SUMMARY
Four cases of presumed ocular histoplasmosis like retinopathy are presented. A detailed immunological assessment was carried out on the patients and a control group: lymphocyte immunophenotyping; flow cytometric analysis; HLA typing and $T$ cell receptor variable region (TCR $V$ region) expression were assessed. Analysis of TCR $V$ region expression revealed no significant preferential expression. HLA typing also failed to reveal any links. All lymphocyte markers analysed were unremarkable, with the exception of CD38 which was significantly raised compared with controls $(p<0.01)$. This finding was confirmed by the use of two different CD38-specific monoclonal antibodies. The raised CD38 in our cases was shown to be persistent when the patients were retested after an interval of several months. Significantly, this may correlate with poor $T$ cell function, as in Common Variable Immunodeficiency, making these patients more susceptible to various stimuli.
\end{abstract}

The association of haemorrhagic macular lesions with histoplasmosis was noted as early as $1942,{ }^{1}$ but the syndrome of presumed ocular histoplasmosis (POHS) was not suggested until $1960 .^{2}$ The description of disciform lesions at the macula, accompanied by multiple, peripheral, discrete atrophic spots was extended to include peripapillary pigment epithelial atrophy ${ }^{3}$ and the absence of aqueous and vitreous inflammation. ${ }^{4}$ The inclusion of peripheral linear streak lesions was made later. ${ }^{5}$ A condition with identical fundal changes is seen in Europe although it is much less common and the patients are virtually always reported as having negative histoplasmin reactivity. ${ }^{6,7}$

From: Southampton University Hospitals, Departments of Ophthalmology and Immunology, Tremona Road, Southampton SO9 4XY, UK

Correspondence to: Mr P. Hodgkins, Department of Ophthalmology, Clinic 3, Addenbrooke's Hospital, Hills Road, Cambridge CB2 2QQ, UK.

Eye (1995) 9, 56-63 C 1995 Royal College of Ophthalmologists
POHS is endemic in certain areas of the United States (Ohio-Mississippi River valley), although its relationship to infection with Histoplasma capsulatum remains uncertain even there. The association between this ocular syndrome and $H$. capsulatum rests on epidemiological data ${ }^{2}$ which have not been without controversy.

Further doubt about the role of $H$. capsulatum comes from what has been called the 'earth day' study. $^{7}$ In this survey hundreds of schoolchildren were simultaneously exposed to $H$. capsulatum and subsequently became seropositive. They developed systemic histoplasmosis, a febrile illness with headache and chest pain. A similar number of children showed elevated Histoplasma titre but did not develop the systemic disease. These cases have been followed for many years and no significant difference in the rate of occurrence of the ocular syndrome has yet been reported compared with control groups. $^{7}$

The assumption that POHS has a single aetiology may prove groundless. There are already several conditions described as causing POHS-like lesions. ${ }^{8}$ Retinal lesions resembling POHS have also been reported in Fuch's heterochromic cyclitis, ${ }^{9}$ punctate inner choroidopathy (PIC) ${ }^{10}$ and myopia. However, there remain a number of patients in the United Kingdom who are given the diagnosis of POHS-like retinopathy in the absence of a better aetiological definition.

The immunological aspects of POHS have not been studied in any detail even in the United States, where there appear to be many more cases. ${ }^{11}$ It is clear that there is significant difficulty in finding and interpreting systemic changes in immune function in a disease that apparently presents with only ocular findings. In this study we have taken the opportunity to make detailed immunological examination of the peripheral blood lymphocytes in four cases of POHS- 


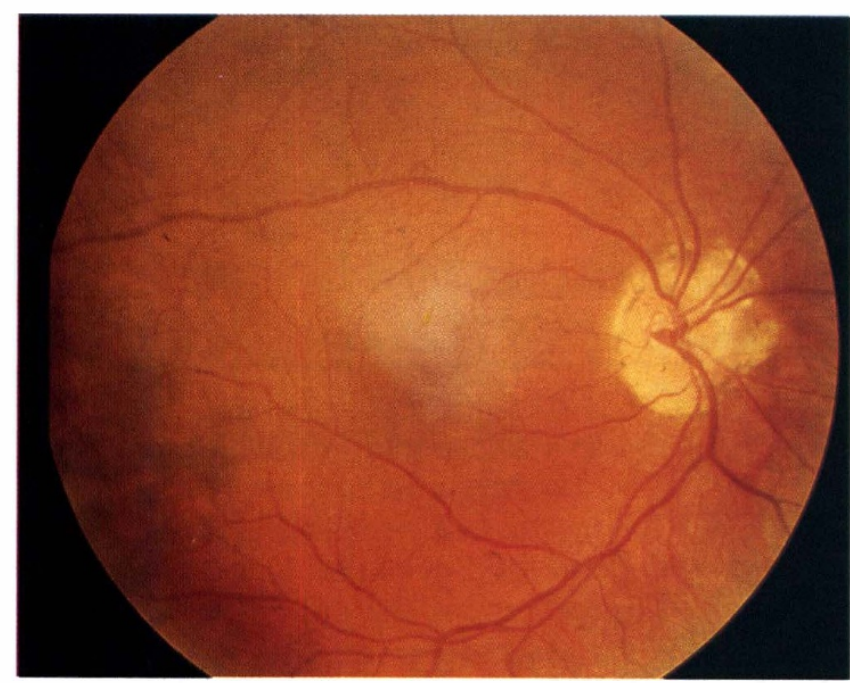

Fig. 1. Case 1. Late picture of right fundus after resolution of fluid, with macula scar and peripapillary atrophy.

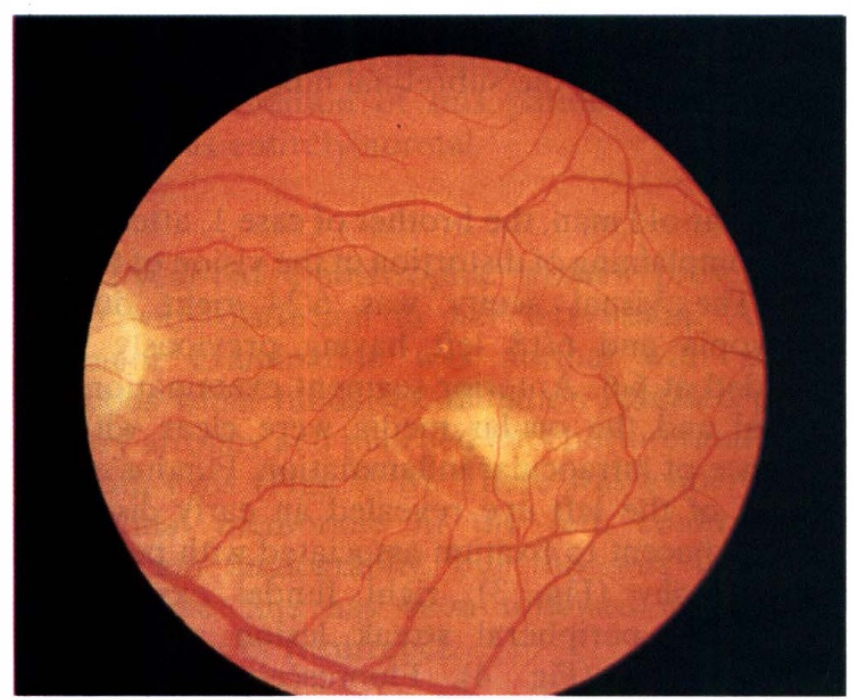

Fig. 3. Case 2. Left central subretinal neovascular membrane and peripapillary atrophy.

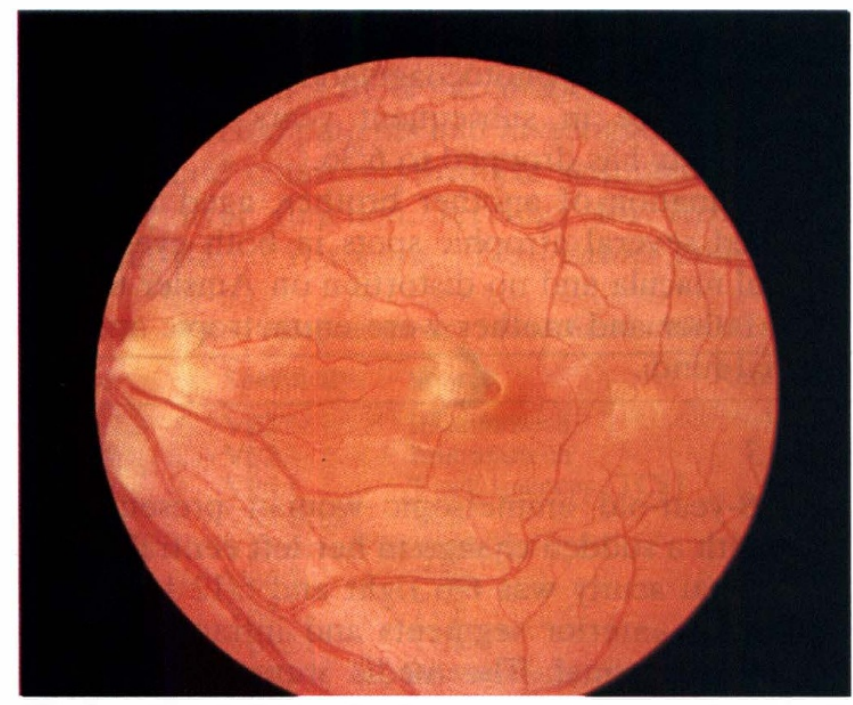

Fig. 5. Case 3. Left subretinal neovascular membrane with early peripapillary atrophy and atrophic spots.

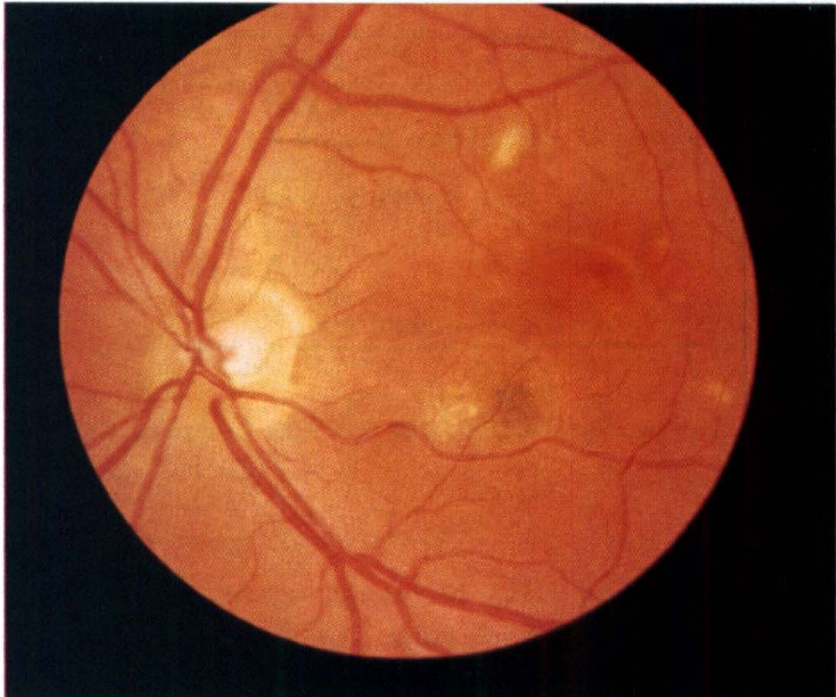

Fig. 2. Case 1. Left subretinal neovascular membrane and discrete atrophic spots.

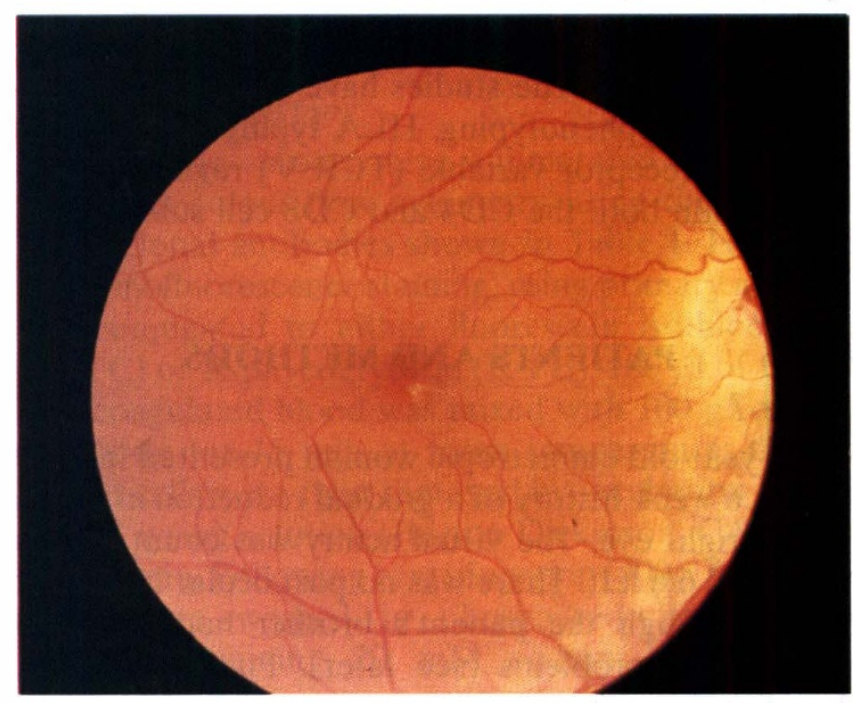

Fig. 4. Case 2. Central atrophic lesions and peripapillary atrophy in right fundus.

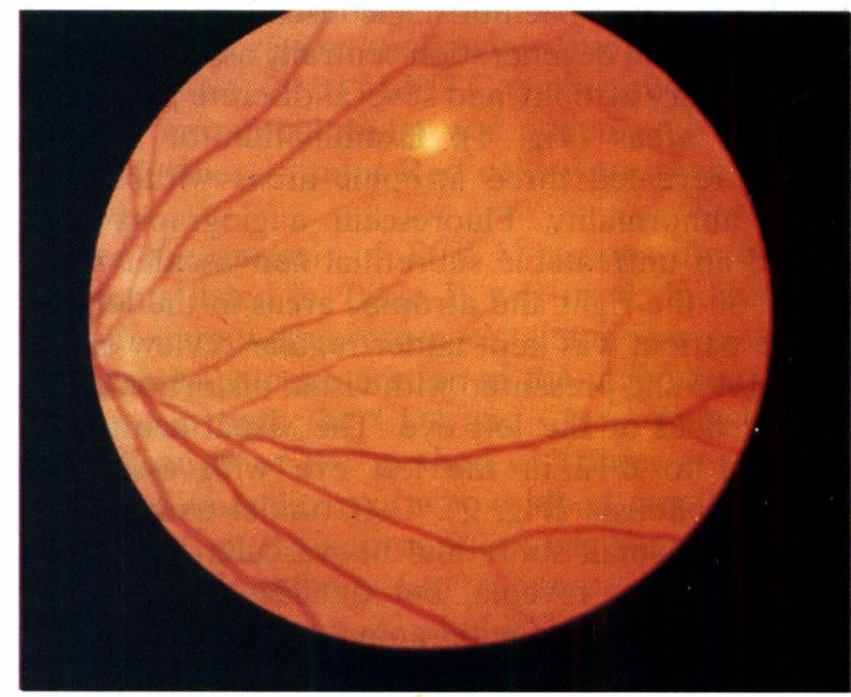

Fig. 6. Case 3. Right fundus with peripheral atrophic spot. 


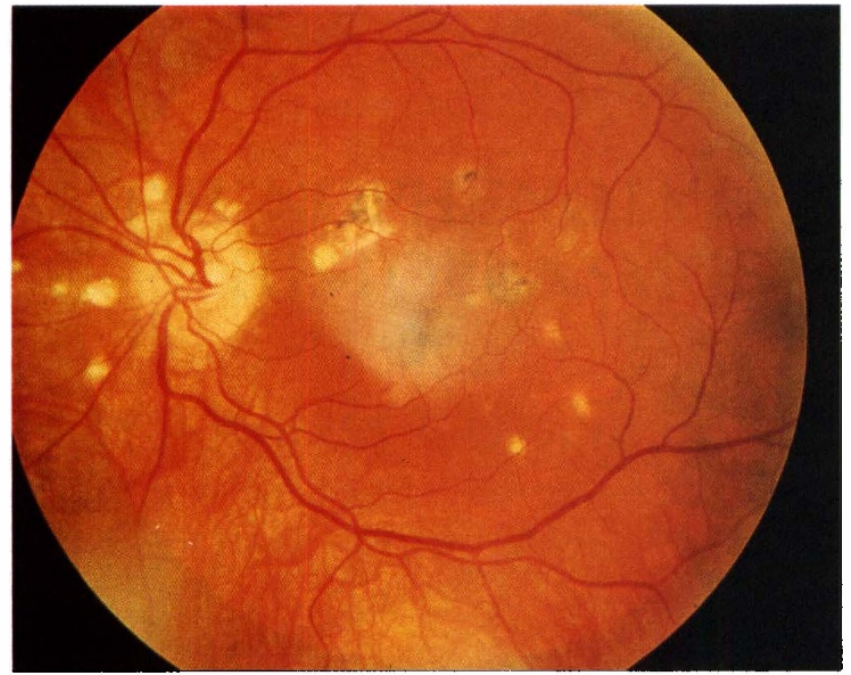

Fig. 7. Case 4. Left fundus with peripapillary atrophy, punched out with spots and a subretinal neovascular membrane.

like retinopathy. The studies have included lymphocyte immunophenotyping, HLA typing and analysis of $\mathrm{T}$ cell receptor variable (TCR V) region expression within both the CD4 and CD8 cell subsets.

\section{PATIENTS AND METHODS}

\section{Case 1}

A 20-year-old emmetropic woman presented in 1990 with a 6 week history of a gradual reduction in vision of the right eye. The visual acuity was count fingers right and $6 / 6$ left. There was no past ocular history of note although the patient's brother had also had similar eye problems (see later). Pupil responses, anterior segments and intraocular pressures were normal. There was no evidence of any intraocular inflammation. Examination of the right fundus revealed a large haemorrhagic disciform lesion with a cystic retinal degeneration centrally associated with peripapillary atrophy and several discrete peripheral atrophic areas (Fig. 1). Examination of the left fundus revealed three atrophic areas without any other abnormality. Fluorescein angiography confirmed an untreatable subretinal neovascular membrane on the right and atrophic areas in the left.

The patient was kept under regular review and in early 1993 she presented with visual distortion of the central field of the left eye. The visual acuity had dropped to $6 / 12$ in the left eye with associated metamorphopsia (Fig. 2). Left fundal examination revealed a small subretinal neovascular membrane just below the foveola, but outside the avascular zone. Fluorescein angiography confirmed this and showed the lesion to be treatable. Laser therapy was performed and the visual acuity has since returned to $6 / 6$ and has remained at that level. The visual acuity

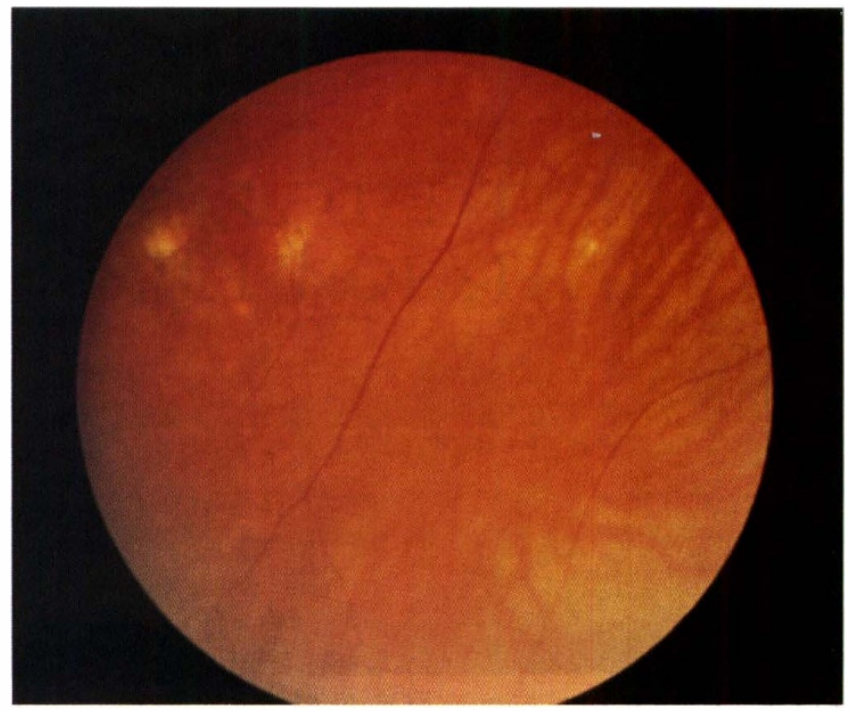

Fig. 8. Case 4. Peripheral atrophic spots in right fundus.

in the right eye improved to $6 / 36$ with the disappearance of the subretinal fluid.

\section{Case 2}

A 22-year-old man, the brother of case 1, attended in 1989 complaining of distortion of the vision of the left eye. The visual acuity was $6 / 24$ right due to amblyopia and 6/18 left having previously been recorded at 6/6. Anterior segment examination was normal and the ocular media were clear with no evidence of intraocular inflammation. Fundus examination of the left eye revealed an early disciform lesion adjacent to fixation associated with peripapillary atrophy (Fig. 3); right fundal examination revealed a peripheral streak lesion and central atrophic spot (Fig. 4). Fluorescein angiography revealed a neovascular process beneath and temporal to the fovea with surrounding subretinal blood. There were also several hyperfluorescent spots in the periphery. It was felt that the patient was unlikely to benefit from laser photocoagulation. There has been no recurrence in subsequent years although the visual acuity has dropped to $6 / 36$.

Examination of another brother, aged 22 years, revealed several atrophic spots in both eyes but a normal macula and no distortion on Amsler testing. Both father and mother were emmetropic and had normal fundi.

\section{Case 3}

An 18-year-old emmetropic woman presented in 1990 with a sudden change in her left central vision. The visual acuity was $6 / 6$ right and 6/12 left. Pupil responses, anterior segments and intraocular pressure were normal. The media were clear without evidence of any inflammation. The left fundus revealed a subretinal neovascular membrane that 
Table I. Monoclonal antibodies used

\begin{tabular}{llll}
\hline Clone & Specificity & Cellular expression & Source \\
\hline UCHT1 & CD3 & T cells & Prof. P. Beverley \\
OKT4 & CD4 & T helper cells & American Type Culture Collection (ATCC) \\
OKT8 & CD8 & T cytotoxic/suppressor cells & ATCC \\
FMC63 & CD19 & B cells & Prof. H. Zola \\
HNK1 & CD57 & NK cells & ATCC \\
OKT10 & CD38 & Activated T cells & ATCC \\
AT13/5 & CD38 & Activated T cells & ATCC \\
WR18 & HLA Class 2 & B cells, monocytes, activated T cells & Wessex Immunology Service \\
\hline
\end{tabular}

was confirmed on fluorescein angiography to be beneath the avascular zone and was considered to be untreatable (Fig. 5). This was associated with several discrete atrophic lesions in both fundi (Fig. 6). Over the next 2 years the left acuity dropped to counting fingers with the development of peripapillary atrophy. At no time was there any indication of intraocular inflammation. The right eye has remained quiet with $6 / 6$ vision.

The younger brother of this patient had developed shingles at the age of 8 years with a recurrence more recently, having had chicken pox when 4 years old. Ocular examination of this patient and both the parents was entirely normal.

\section{Case 4}

A 32-year-old emmetrophic woman presented in 1990 with distortion in her left vision. Anterior segment examination was normal with a quiet vitreous while fundal examination revealed peripapillary atrophy and punched out chorioretinal lesions in both eyes (Figs. 7, 8). There was evidence of a subretinal membrane in the left, confirmed on fluorescein angiography, but this was felt to be untreatable. She has been followed in the clinic with no sign of recurrence.

The patients were all well and apyrexial at the time of re-examination. There was no evidence of optic disc drusen or angioid streaks. They had never lived abroad and only visited Europe on one occasion, and they had all had a BCG vaccination when at school. All the affected patients had investigations including a full blood count, erythrocyte sedimentation rate, VDRL, liver function, serology for Histoplasma, Epstein-Barr, Toxocara, Toxoplasma and Crypto-

Table II. T cell receptor specific monoclonal antibodies used

\begin{tabular}{lllc}
\hline Clone & Specificity & Source & Reference \\
\hline E22E7.2 & V $\beta 2$ & Immunotech & 13 \\
LE-89 & V $\beta 3$ & Immunotech & 14 \\
LC4 & V $\beta 5.1$ & T cell sciences (TCS) & 15 \\
1C1 & V $\beta 5.2 / 5.3$ & TCS & 16 \\
W112 & V $\beta 5.3$ & TCS & 17 \\
OT145 & V $\beta 6.7$ & TCS & 18 \\
16G8 & V $\beta 8.1$ & TCS & 16 \\
S511 & V $\beta 12.1$ & TCS & 19 \\
JU74 & V $\beta 13.3$ & Immunotech & 14 \\
BA-62 & V $\beta 17$ & Immunotech & 14 \\
E17.5F3.13 & V $\beta 19$ & Immunotech & 13 \\
\hline
\end{tabular}

coccus, sputum culture and chest radiograph. These were all normal.

\section{Control Group}

The control group consisted of 25 healthy age- and sex-matched subjects who had their lymphocyte markers analysed.

In addition lymphocyte immunophenotyping, HLA typing and analysis of TCR V region expression within both the CD4 and CD8 cell subsets was performed on all cases.

\section{Immunophenotyping}

Lymphocyte subsets were enumerated using single and dual colour flow cytometry using the panel of monoclonal antibodies shown in Table I. For direct immunofluorescence staining, using primary antibodies conjugated to either fluorescein isothiocyanate (FITC) or R-phycoerythrin (R-PE), $100 \mu$ of EDTA anticoagulated blood was mixed with $100 \mu$ of each antibody for $15 \mathrm{~min}$ at room temperature; the red blood cells were then removed by incubation in $2 \mathrm{ml}$ FACS lysing solution (Becton Dickinson, CA, USA) for $10 \mathrm{~min}$. Following centrifugation $(400 \mathrm{~g}, 5 \mathrm{~min})$ the cells were washed in phosphate-buffered saline (PBS) containing $20 \mathrm{mM}$ sodium azide before analysis.

For indirect immunofluorescence staining, $100 \mu \mathrm{l}$ of whole blood was incubated with $10 \mu$ l of unconjugated primary antibody for $15 \mathrm{~min}$ at room temperature. Following one wash in PBS (400g, $5 \mathrm{~min}$ ) $20 \mu \mathrm{l}$ of FITC-conjugated sheep antimouse immunoglobulin was added and incubated for a further $15 \mathrm{~min}$. Red cells were then lysed as above.

For the analysis of TCR V regions the panel of reagents listed in Table II was used. Indirect dual colour immunofluorescence staining was performed to permit the enumeration of the individual TCR V regions in both the $\mathrm{CD} 4$ and $\mathrm{CD} 8$ subsets using a modification of the method of Lanier et al. ${ }^{12}$ One hundred microlitres of whole blood were incubated with $10 \mu \mathrm{l}$ of the appropriate TCR V region specific monoclonal antibody for $15 \mathrm{~min}$ at room temperature. After washing, $20 \mu \mathrm{l}$ of FITC-conjugated sheep anti-mouse immunoglobulin was added and incubated for a further $15 \mathrm{~min}$. The cells were washed once more and $10 \mu \mathrm{l}$ of R-PE conjugated anti-CD4 
Table III. Lymphocyte immunophenotyping results in patients $(n=4)$

\begin{tabular}{lcccccrr}
\hline Case & CD3+ve cells & CD3/CD4+ve cells & CD3/CD8+ve cells & CD19 & CD38+ve T cells & CD57 & HLA class 2+T cells \\
\hline 1 & 55 & 34 & 16 & 20 & 55 & 4 & 2.6 \\
2 & 48 & 30 & 15 & 23 & 49 & 11 & 2.5 \\
3 & .72 & 44 & 29 & 16 & 42 & 9 & 1.5 \\
4 & 58 & 37 & 19 & 21 & 50 & 8 & 2.1 \\
\hline
\end{tabular}

Table IV. Lymphocyte immunophenotyping results in controls $(n=25)$

\begin{tabular}{lcc}
\hline Controls & CD3+ve cells & CD38+ve T cells \\
\hline 1 & 72 & 6 \\
2 & 67 & 4 \\
3 & 85 & 7 \\
4 & 67 & 4 \\
5 & 82 & 3 \\
6 & 75 & 4 \\
7 & 75 & 4 \\
8 & 71 & 4 \\
9 & 80 & 4 \\
10 & 81 & 3 \\
11 & 82 & 2 \\
12 & 88 & 2 \\
13 & 73 & 0 \\
14 & 75 & 8 \\
15 & 75 & 0 \\
16 & 69 & 2 \\
17 & 69 & 2 \\
18 & 63 & 4 \\
19 & 66 & 1 \\
20 & 76 & 2 \\
21 & 66 & 7 \\
22 & 83 & 6 \\
23 & 69 & 2 \\
24 & 77 & 6 \\
25 & 78 & 1 \\
\hline
\end{tabular}

or anti-CD8 was added without further washing and incubated for a further $15 \mathrm{~min}$ before red cell lysis as described above.

\section{Flow Cytometric Analysis}

After staining as described, samples were analysed on a FACScan flow cytometer using LYSYS 2 software (Becton Dickinson), with 10000 cells being acquired per sample. A lymphocyte gate was constructed using the principle of forward and side scatter characteristics; fluorescent staining was determined by a two-dimensional dot-plot display. Positively stained cells were enumerated using quadrant statistics, with reference to appropriate negative controls.

\section{HLA Typing}

HLA class 1 typing was carried out using standard NIH cytotoxicity methods. ${ }^{13}$ HLA class 2 typing was carried out using the method of Kimura and Sasazuki. ${ }^{14}$

\section{RESULTS}

The immunophenotypes of the lymphocyte subsets for the patients studied are shown in Table III. All the lymphocyte markers analysed showed unremark- able results with the exception of CD38. T lymphocyte CD38 expression was found to be significantly $(p<0.01)$ above that found in normal subjects (Table IV). These findings were confirmed by the use of two different CD38-specific monoclonal antibodies, which gave similar results in all cases on two separate occasions several months apart. Interestingly the younger brother who had developed shingles and then a recurrence while still under 9 years old also had elevated CD38 at the two separate tests.

Analysis of TCR V region family expression within the CD3-positive cell population revealed no significant preferential expression of any TCR V region family compared with that found in normal controls (see Tables IV, V). Further analysis of TCR $\mathrm{V}$ region expression within the CD4 and CD8 cell subsets also failed to reveal significant bias in TCR V region expression between the CD4 and CD8 cells (Table VI). Although other family members were tested the results were normal and the data are not shown.

The results of the tissue typing studies performed are summarised in Table VII.

\section{DISCUSSION}

This study was prompted when the 8-year-old younger brother of one of our patients with POHSlike retinopathy developed shingles. This led us to investigate the immunological function of four of our patients: two related individuals, the sister of the child who developed shingles, and another spontaneous case. There were no other findings to suggest any other familial problems and these patients seemed to provide a good starting point from which to look for any abnormality. We recognise that these patients may represent only a subset of the larger group labelled POHS retinopathy. Other causes had been excluded, with a full laboratory investigation of each patient revealing no abnormalities (see Results). Tiedeman ${ }^{20}$ reported evidence of acute antibody production to Epstein-Barr virus in patients with multifocal choroiditis, but we did not find that in this group.

Systemic immunological alterations are rare in diseases of the eye. However, significantly increased levels of serum interleukin-2 (IL-2) receptors have been found in various forms of uveitis, ${ }^{21}$ including Fuchs' iridocyclitis where both $\mathrm{T}$ and $\mathrm{B}$ cells are activated. During the first part of this study we 
Table V. TCR V region expression (\%CD3+ve cells) in patients

\begin{tabular}{|c|c|c|c|c|c|}
\hline TCR V region & Case 1 & Case 2 & Case 3 & Case 4 & Normal range \\
\hline$\overline{\mathrm{V} \beta 2}$ & 6.1 & 9.5 & 5.7 & 7.6 & $4.9-9.8$ \\
\hline$V \beta 3$ & 2.5 & 1.6 & 2.6 & 1.9 & $0.8-5.7$ \\
\hline VB5.1 & 3.9 & 2.6 & 3.6 & 3.1 & $1.1-5.6$ \\
\hline$V \beta 5.2 / 5.3$ & 3.8 & 2.8 & 2.9 & 3.2 & $0.9-4.0$ \\
\hline V $\beta 5.3$ & 0.7 & 0.9 & 1.0 & 0.7 & $0.6-1.0$ \\
\hline$V \beta 6.7$ & .5 .4 & 4.1 & 2.5 & 3.2 & $0.0-5.2$ \\
\hline$V(38.1$ & 5.2 & 3.5 & 3.2 & 4.1 & $1.8-6.2$ \\
\hline$V \beta 12.1$ & 1.3 & 1.4 & 1.8 & 1.9 & $1.1-2.4$ \\
\hline$V \beta 13.3$ & 1.0 & 1.4 & 2.1 & 1.2 & $0.5-2.0$ \\
\hline VB17 & 0.3 & 0.4 & 0.5 & 0.7 & $0.0-1.0$ \\
\hline$V \beta 19$ & 5.0 & 5.1 & 3.9 & 6.1 & $3.2-7.4$ \\
\hline
\end{tabular}

Table VI. TCR V region expression in CD4 and CD8 cells in patients

\begin{tabular}{|c|c|c|c|c|c|c|c|c|}
\hline \multirow[b]{2}{*}{ TCR V region } & \multicolumn{2}{|c|}{ Case 1} & \multicolumn{2}{|c|}{ Case 2} & \multicolumn{2}{|c|}{ Case 3} & \multicolumn{2}{|c|}{ Case 4} \\
\hline & $\mathrm{CD} 4$ & CD8 & CD4 & CD8 & CD4 & CD8 & CD4 & $\mathrm{CD} 8$ \\
\hline$V \beta 2$ & 6.1 & 6.0 & 8.7 & 10.5 & 6.6 & 4.4 & 7.2 & 6.1 \\
\hline$V \beta 3$ & 2.1 & 3.4 & 1.7 & 1.5 & 2.4 & 2.9 & 2.0 & 3.0 \\
\hline V $\beta 5.1$ & 4.7 & 2.4 & 3.2 & 1.7 & 4.9 & 1.5 & 3.7 & 1.7 \\
\hline$V \beta 5.2 / 3$ & 2.7 & 6.0 & 3.2 & 2.3 & 3.5 & 1.8 & 2.9 & 3.6 \\
\hline VB5.3 & 0.8 & 0.4 & 0.9 & 0.9 & 1.6 & 0.1 & 1.1 & 0.3 \\
\hline VB6.7 & 6.1 & 3.9 & 5.6 & 2.0 & 3.6 & 0.8 & 4.1 & 2.6 \\
\hline$V \beta 8.1$ & 5.6 & 4.4 & 4.3 & 2.4 & 3.0 & 3.5 & 3.7 & 4.0 \\
\hline $\mathrm{V} \beta 12.1$ & 1.0 & 2.0 & 1.2 & 1.7 & 2.6 & 0.6 & 1.4 & 1.4 \\
\hline$V \beta 13.3$ & 1.7 & 1.4 & 1.6 & 1.2 & 2.4 & 1.7 & 1.8 & 1.4 \\
\hline $\mathrm{V} \beta 17$ & 0.4 & 0.2 & 0.5 & 0.2 & 0.8 & 0.0 & 0.6 & 0.1 \\
\hline V $\beta 19$ & 5.5 & 4.1 & 5.9 & 3.9 & 4.5 & 3.0 & 4.7 & 3.6 \\
\hline
\end{tabular}

Table VII. HLA phenotypes

\begin{tabular}{lccc}
\hline Case & HLA-A & HLA-B & HLA-DR \\
\hline 1 & 3.29 & 7.44 & 2.7 \\
2 & 3.24 & 7.27 & 2.4 \\
3 & 32.19 & 5.14 & 3 \\
4 & 17.30 & 3.30 & 4.7 \\
\hline
\end{tabular}

performed cellular immunotyping on the patients and their family members to assess whether a systemic immunological change could be found.

Initial lymphocyte immunophenotyping studies demonstrated that the major lymphocyte subsets were all present in normal proportions and numbers. However, the expression of the CD38 antigen on the $\mathrm{T}$ cells of the patients was significantly $(p<0.01)$ raised and remained so on retesting several months later. Due to the nature of these results we have confirmed the findings by using two monoclonal antibodies and have been able to demonstrate similar results with these reagents.

CD38 is a cell surface antigen normally expressed on most immature haematopoietic cells. It is lost from the cell surface as maturation occurs, so that it is expressed on only a very small number of peripheral blood lymphocytes in normal subjects. ${ }^{22}$ Expression of $\mathrm{CD} 38$ may be induced on mature peripheral blood $\mathrm{T}$ cells following activation, ${ }^{22}$ and it is readily detectable on these cells during and after viral infections. ${ }^{24}$ Recently it has been reported that some patients suffering from common variable immune deficiency (CVID) demonstrate CD38 expression on their blood $\mathrm{T}$ cells and that this expression can be correlated with a state of anergy. ${ }^{23}$ It may therefore be possible that CD38 expression is correlated with a functional $\mathrm{T}$ cell deficiency rather than being a simple marker of activation. As raised CD38 expression was persistently found in our patients it is unlikely that it is just a reaction to a 'POHS' infection. It may represent an indicator of a state of $T$ cell anergy in these patients that predisposes to infection.

$\mathrm{T}$ cell activation is characterised by changes in the surface expression of a number of other antigens in addition to CD38. Following activation the expression of HLA-DR and CD25 is increased on T cells, whilst there is a decrease of Leu-1 expression. These changes occur over a period of $24-48 \mathrm{~h}$, with expression of $\mathrm{CD} 25$ being the first to develop. Analysis of a second marker of $\mathrm{T}$ cell activation, the expression of HLA-DR, showed no increase above the normal range in our patients. This further supports the idea that CD38 expression on these cells is not the result of cellular activation. We have not yet investigated further markers of activation, such as CD25 (the IL-2 receptor). 
As susceptibility to many disease processes is affected by the HLA phenotype of the individual we have performed tissue typing studies on the patients and their families. It is clearly impossible to draw any conclusions regarding links between HLA types and susceptibility in a series of this size, but no clear links could be seen in our study.

The TCR repertoire of peripheral $T$ cells is strongly influenced by the HLA type of the individual. This reflects the processes of positive and negative selection that occur within the thymus, as well as the responses to infectious agents with which the host may have been in contact. In certain cases (e.g. superantigen stimulation) infectious agents may result in the selective expansion of particular TCR V region families. In our cases no evidence of significant expansion of any TCR V region was found when looking at the total $\mathrm{T}$ cell population or at the CD4 and CD8 cell subsets. Although apparent biased expression of TCR V regions was seen between $\mathrm{CD} 4$ and $\mathrm{CD} 8$ in several cases (e.g. V 5.1 expression is higher in the CD4 cells than in the CD8 cells), these findings have been reported in normal subjects ${ }^{24,25}$ and presumably represent the influences of thymic selection processes on these cell subsets.

In summary, we have carefully investigated the immunophenotype and TCR $\mathrm{V}$ region family expression of peripheral blood lymphocytes in patients with POHS-like retinopathy. We have not found any significant deviations from the normal in any of the parameters studied apart from the significantly elevated expression of CD38 on peripheral $\mathrm{T}$ lymphocytes. We speculate that this may reflect an undefined state of hyporesponsiveness in these cells, as in CVID, that may lead to an increased susceptibility to a stimulus which is quite widespread but only infrequently expressed. Further studies of the immune status of patients with POHS-like changes are warranted.

We would like to thank the Wessex Medical Trust for their financial support with this project and $\mathrm{Mr} \mathrm{R}$. Walters (Consultant Ophthalmologist, Cardiff) for his help in its conception.

Key words: CD38, Immunophenotyping, Presumed ocular histoplasmosis.

\section{REFERENCES}

1. Reid JD, Schere JH, Herbut PA, Irving H. Systemic histoplasmosis diagnosed before death and produced experimentally in guinea pigs. J Lab Clin Med 1942;27:219-23.

2. Woods AC, Wahlen HE. The probable role of benign histoplasmosis in the aetiology of granulomatous uveitis. Am J Ophthalmol 1960;49:205-20.

3. Schlaegel TF, Kennery D. Changes around the optic nerve head in presumed ocular histoplasmosis. Am J Ophthalmol 1966;62:454-8.
4. Van Metz TE, Maumenee AE. Specific ocular uveal lesions in patients with evidence of histoplasmosis. Arch Ophthalmol 1964;71:314-24.

5. Foutain JA, Schlaegel TF. Linear streaks of the equator in the presumed ocular histoplasmosis syndrome. Arch Ophthalmol 1981;99:246-8.

6. Braunstein RA, Rosen A, Bird AC. Ocular histoplasmosis syndrome in the UK. Br J Ophthalmol 1974;58: 893-8.

7. Davidorf FH, Anderson JD. Ocular lesions in the Earth Day, 1970, Histoplasmosis epidemic. Int Ophthalmol Clin 1975; 15:51-63.

8. Deutsch TA, Tessler HH. Inflammatory pseudohistoplasmosis. Ann Ophthalmol 1985;17:461-5.

9. Arffa RC, Schlaegal TF. Chorioretinal scars in Fuchs' heterochromic cyclitis. Arch Ophthalmol 1984;102: 1153-5.

10. Watzke RC, Packer AC, Folk JC, Benson WE, Burgess $\mathrm{D}$, Ober RR. Punctate inner choroidopathy. Am J Ophthalmol 1984;98:572-84.

11. Hawkins BS, Ganley JP. Risk of visual impairment attributable to ocular histoplasmosis. Arch Ophthalmol 1994;112:655-66.

12. Lanier LL, Le AM, Ding AH, Evans EL. Analysis of the workshop T-cell monoclonal antibodies by indirect two-colour immunofluorescence and multiparameter flow cytometry. In McMichael AJ, editor. Leucocyte typing III. Oxford: Oxford University Press, 1987.

13. Terasaki PI, Bernoco D, Park MS, Ozturk G, Iwaki Y. Microdroplet testing for HLA-A, B and D antigens. Am J Clin Pathol 1978;69:103-20.

14. Kimura A, Sasazuki T. Eleventh International Histocompatibility Workshop reference protocol for the HLA DNA typing technique. In Tsuji K, et al., editors. Proceedings of the Eleventh International Histocompatibility Workshop and Conference. Oxford: Oxford University Press, 1993.

15. Romagne F, Besnaddeau L, Malissen B. A versatile method to produce antibodies to human $\mathrm{T}$ cell receptor $\mathrm{V}$ beta segments: frequency determination of human $\mathrm{V}$ beta $2+\mathrm{T}$ cells that react with toxic-shock syndrome toxin 1. Eur J Immunol 1992;22:2749.

16. Diu A, Romagne F, Genevee C, Rocher C, Bruneau JM, David A, Praz F, Hercend T. Fine specificity of monoclonal antibodies directed at human $\mathrm{T}$ cell receptor variable regions: comparison with oligonucleotide driven amplification for evaluation of $\mathbf{V b}$ expression. Eur J Immunol 1993;23:1422-9.

17. Maecker H, Levy R. Prevalence of antigen receptor variants in human $\mathrm{T}$ cell lines and tumours . J Immunol 1989;142:1395-404.

18. Boylston A, Borst J, Yssel H, Blanchard D, Spits H, De Vries J. Properties of a panel of monoclonal antibodies which react with the human $T$ cell antigen receptor on the leukemic line HPB-ALL and a subset of normal peripheral blood T lymphocytes. J Immunol 1986;137: 741-4.

19. Tian W-T, Skibbens R, Kubinec J, Henry L, Ko J-L, Yeh G, Ip S. Monoclonal antibodies specific to human $\mathrm{T}$ cell antigen receptor V-beta gene products. FASEB J 1989;3:A486.

20. Tiedeman JS. Epstein Barr viral antibodies in multifocal choroiditis and panuveitis. Am J Ophthalmol 1987;103:659-63.

21. Arocker-Mellinger E, Asenbauer T, Ulbrich S, Grabner G. Serum interleukin 2 receptor levels in uveitis. Curr Eye Res (Suppl) 1990;9:25-9.

22. Hercend T, Ritz J, Schlossman SF. Comparative expression of T9, T10 and Ia antigens on activated 
human T cells subsets. Hum Immunol 1981;3:247-59.

23. Vukmanovic S, Vuckovic S, Stosic-Grujicic S, Ramic Z, Abinun M. An unusual T cell surface phenotype in vivo correlates with the failure to proliferate and produce IL-2 in vitro in a patient with common variable immunodeficiency. Clin Immunol Immunopathol 1992;65:261-70.
24. Davey MP, Meyer MM, Bakke AC. T cell receptor VB gene expression in monozygotic twins. J Immunol 1994;152:315-21.

25. Grunewald J, Janson CH, Wigzell H. Biased expression of individual $\mathrm{T}$ cell receptor $\mathrm{V}$ gene segments in CD4+ and CD8+ human peripheral blood T lymphocytes. Eur J Immunol 1991;21:819-22. 